\title{
Experimental evidence for fluid-induced melting in subduction zones
}

\author{
G. Rustioni ${ }^{1}$, A. Audétat ${ }^{1}$, H. Keppler ${ }^{1 *}$
}

Abstract

OPEN ACCESS

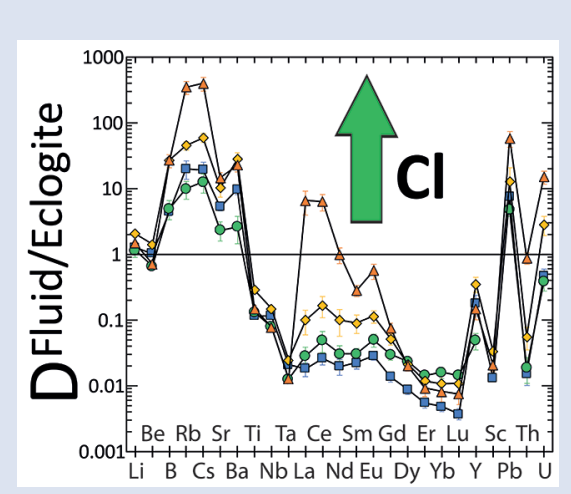

\begin{abstract}
Although subduction zones are the main source of seismic and volcanic hazards on Earth, the causes of melting in volcanic arcs are still not fully understood. Recent models suggested that melting in the mantle wedge is not caused by hydrous fluids, but by sediment melts ascending from the subducted slab. A main argument for these models was that hydrous fluids are "too dilute" to produce the trace element enrichment observed in arc magmas. Here we demonstrate experimentally that even moderate salinities enhance the partitioning of trace elements such as the light rare earths, alkalis, alkaline earths, $\mathrm{Pb}$, and $\mathrm{U}$ into the fluid by several orders of magnitude. Our data therefore show that saline hydrous fluids released from the basaltic part of the oceanic crust may produce the enrichment in LILE and light REE elements, and the negative $\mathrm{Nb}$-Ta anomaly observed in typical arc magmas.
\end{abstract}

Received 7 June 2019 | Accepted 28 August 2019 | Published 22 October 2019

\section{Introduction}

In subduction zones, oceanic crust is recycled into the mantle. Thermal models show that the temperature of the mantle wedge above the subducting slab is actually considerably lower than in other parts of the shallow upper mantle (Syracuse et al., 2010). Melting must therefore be caused by other effects, most likely by the addition of water, which may reduce the melting temperatures of mantle peridotite by several $100{ }^{\circ} \mathrm{C}$ (Kawamoto and Holloway, 1997; Gaetani and Grove, 1998). Water may be transferred from the subducted oceanic slab to the mantle wedge in the form of aqueous fluids, released by the dehydration of hydrous minerals, or by sediment melts. Already early studies (Perfit et al., 1980; Arculus and Powell, 1986) noted that the trace element enrichment pattern in magmas from volcanic arcs above a subduction zone is distinctly different from that observed in magmas at divergent plate boundaries, e.g., mid-ocean ridges. Typical features of arc magmas include high enrichments of large ion lithophile elements (LILE, such as $\mathrm{Rb}^{+}, \mathrm{Cs}^{+}, \mathrm{Sr}^{2+}, \mathrm{Ba}^{2+}$ ) and light rare earth elements (REE, such as $\mathrm{La}^{3+}$ and $\left.\mathrm{Ce}^{3+}\right)$, but strong depletions of high field strength elements (HFSE, such as $\mathrm{Ti}^{4+}, \mathrm{Nb}^{5+}$ and $\mathrm{Ta}^{5+}$ ). Some experimental studies (Kessel et al., 2005; Hermann et al., 2006) suggested that trace element transport by aqueous fluids is unable to produce the observed trace element enrichment pattern in arc magmas. This led to the suggestion that sediment melts are the main agents of metasomatism in the mantle wedge above subduction zones (Kelemen et al., 2005; Hermann et al., 2006; Skora and Blundy, 2010; Behn et al., 2011; Spandler and Pirard, 2013). Previous studies, however, did not consider the effect of chloride, which may affect the partition behaviour of various trace elements by the formation of chloride complexes in the fluid. As the subducted oceanic crust was in contact with seawater, it is expected to contain chloride and measurements of the $\mathrm{Cl} / \mathrm{H}_{2} \mathrm{O}$ ratio of primitive arc magmas (Métrich and Wallace, 2008), as well as other lines of evidence (Kawamoto et al., 2013), are consistent with the incorporation of aqueous fluids (Manning, 2004) containing up to 15 wt. $\% \mathrm{NaCl}$. In the present study, we therefore for the first time directly measured the effect of chlorine on the partitioning of trace elements between aqueous fluids and the minerals of the subducted basaltic crust at conditions corresponding to the typical depth of the slab below the volcanic front.

\section{Methods}

Experiments were carried out in an end-loaded piston cylinder apparatus (Boyd and England, 1960) at 4 GPa and $800{ }^{\circ} \mathrm{C}$ with run durations between 2 and 7 days. Synthetic MORB (mid-ocean ridge basalt) glass doped with a suite of trace elements was loaded together with water or $\mathrm{NaCl}$ solutions into platinum capsules. A layer of diamond powder was inserted in the middle of the capsule between the layers of MORB powder to provide some empty pore space between the diamond grains for trapping the fluid (Ryabchikov et al., 1989). After quenching of the experiments, the sample capsules were cooled to liquid nitrogen temperature and cut in half. Both the compositions of the minerals and of the quenched fluid trapped between the diamond grains were then measured

\footnotetext{
1. Bayerisches Geoinstitut, Universität Bayreuth, 95440 Bayreuth, Germany
} * Corresponding author (email: hans.keppler@uni-bayreuth.de) 

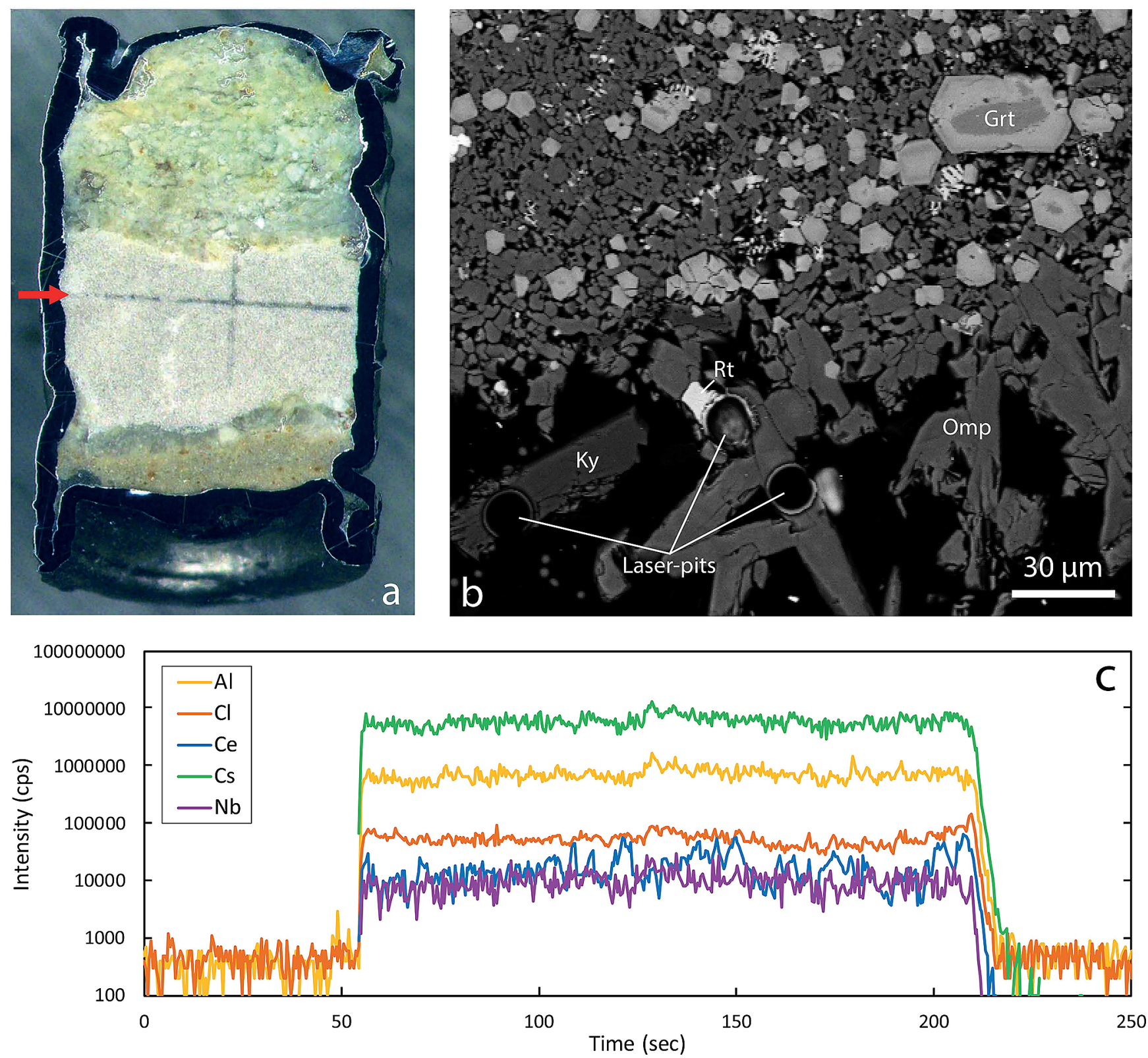

Figure 1 Run products from high pressure experiments. (a) Cross section of a sample capsule after an experiment (image width 5 $\mathrm{mm})$. A white layer of diamond powder is sandwiched between the silicate sample. The red arrow points to a laser ablation trace. (b) Backscatter electron image of the silicate part of a sample, consisting mostly of omphacite (Omp) and garnet (Grt) with minor kyanite (Ky) and rutile (Rt). In the centre of some garnet crystals, remnants of the garnet seeds are visible. (c) Laser ablation analysis of frozen fluid in the diamond trap, demonstrating the homogeneity of the sample.

in frozen state (Kessel et al., 2005) by laser ablation ICP-MS. Additional details about the experimental and analytical methods are given in the Supplementary Information.

\section{Results and discussion}

During the high pressure experiments, the glasses recrystallised to an eclogitic assemblage of omphacite, garnet, rutile, and kyanite, i.e. the same minerals that are expected to be stable in the subducted basaltic oceanic crust below the volcanic arc (Fig. 1). Other accessory phases likely do not occur in natural MORB at eclogite facies conditions. The solubility of phosphorus in garnet is so high that apatite and other phosphates are unlikely to form (Konzett and Frost, 2009). Due to the very low $\mathrm{K}_{2} \mathrm{O}$ content in natural MORB, eclogites of MORB composition either contain no phengite at all or at most traces of this mineral (e.g., Okrusch et al., 1991; see also the
Supplementary Information for further discussion). Indeed, in sub-solidus experiments with natural MORB at $3 \mathrm{GPa}$ and $800{ }^{\circ} \mathrm{C}$, Carter et al. (2015) did not observe any phengite or apatite.

Mineral compositions in our experiments were found to be uniform in the entire sample, consistent with attainment of equilibrium throughout the entire charge. With a few exceptions, as discussed below, laser ablation ICP-MS analyses of trace element concentrations yielded homogeneous compositions of both the quenched fluid phase and the minerals (see Fig. 1 for typical laser ablation signals). Fluid/mineral partition coefficients $\mathrm{D}^{\text {fluid/mineral }}=\mathrm{c}^{\text {fluid }} / \mathrm{c}^{\text {mineral }}$ were calculated from the measured trace element concentrations in fluid ( $\mathrm{c}^{\text {fluid }}$ ) and coexisting minerals ( $\mathrm{c}^{\text {mineral }}$ ). Bulk fluid/eclogite partition coefficients were then calculated from the individual fluid/mineral partition coefficients assuming an eclogitic mineralogy with 59 $\%$ omphacite, $39 \%$ garnet and $2 \%$ rutile. Experimental details, 

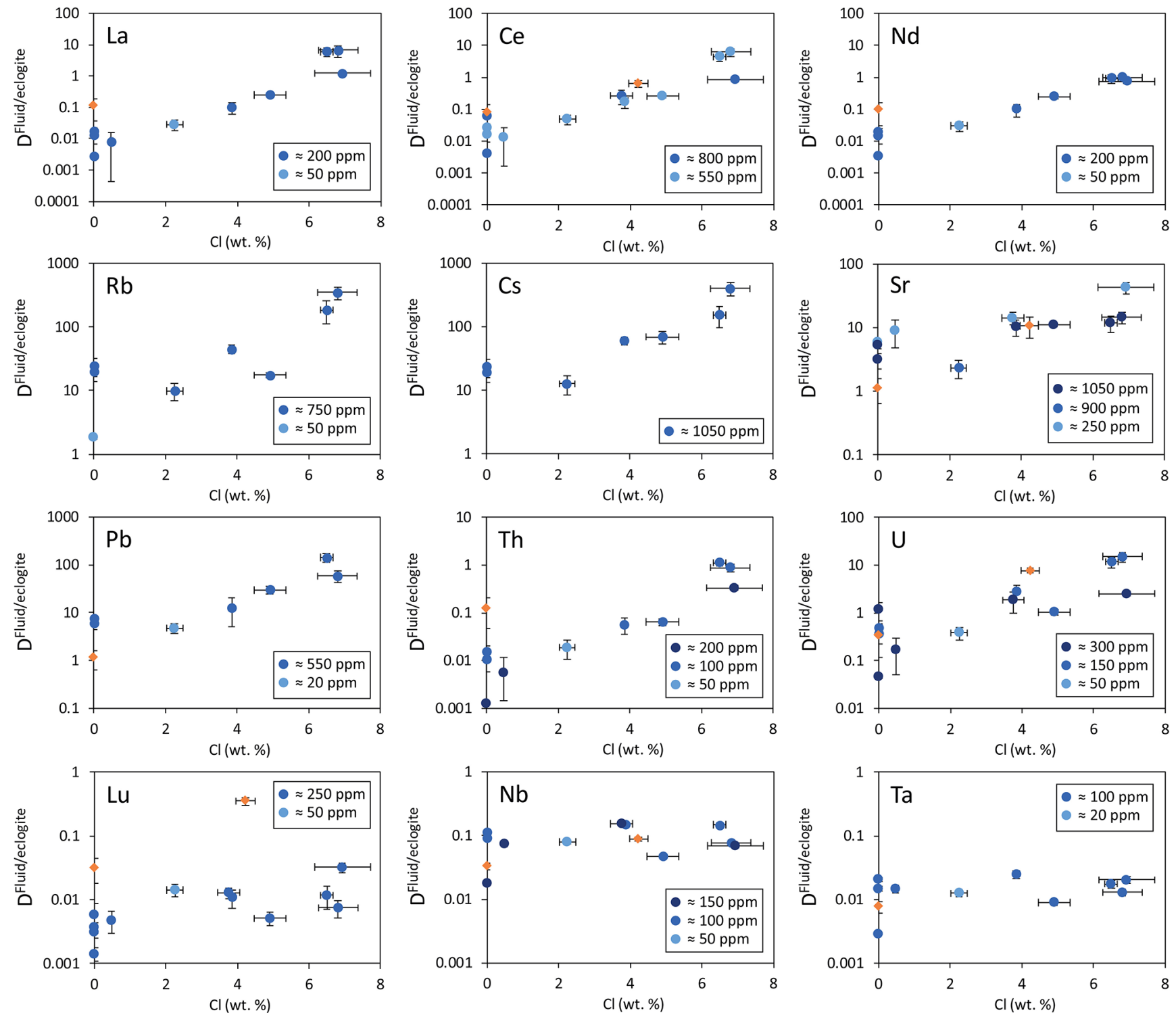

Figure 2 Effect of chloride on fluid/eclogite partition coefficients of trace elements at $4 \mathrm{GPa}$ and $800{ }^{\circ} \mathrm{C}$. Blue data points are the results from "forward" experiments, where the trace elements were initially doped into the solid starting material, while orange data points are from "reversed" experiments, which started with all trace elements dissolved in the fluid. For the forward experiments, results for different initial trace element concentrations in the starting material are given. Error bars are one standard deviation. Data for these and additional elements are given in Tables S-1 to S-8.

compositions of all phases and calculated bulk fluid eclogite partition coefficients are compiled in Tables S-1 to S-8 of the Supplementary Information.

A major problem in all studies of element partitioning between minerals and fluid is attainment of equilibrium, since the diffusion coefficients of most of the relevant trace elements in the minerals are very low. In order to circumvent this problem, we introduced periodic temperature fluctuations by $\pm 30{ }^{\circ} \mathrm{C}$ in our experiments, which enhanced grain growth and equilibration by Ostwald ripening (i.e. the dissolution of smaller grains at higher temperature and the growth of larger grains upon cooling). Indeed, the resulting grain sizes observed after runs with these sinusoidal temperature fluctuations were generally much larger than for experiments at constant temperature, but mineral compositions were not affected. In order to demonstrate conclusively the attainment of equilibrium, we also performed some reversed experiments, starting with a trace element-free MORB glass and trace element-doped solutions. In general, both the normal "forward" experiments starting with trace element-doped MORB glass and the reversed experiments gave very consistent results. We are therefore confident that the trace element partition coefficients reported here represent true chemical equilibrium between aqueous fluid and minerals. Moreover, results from experiments with different concentration levels of trace elements yielded consistent partition coefficients, implying that Henry's law is fulfilled.

Figure 2 shows the fluid/eclogite partition coefficients for some selected trace elements as a function of the chloride content in the fluid. For the light rare earths, such as La and $\mathrm{Ce}$, there is a striking increase of $\mathrm{D}^{\text {fluid/eclogite }}$ by up to three orders of magnitude even for moderate salinities (up to 15 wt. \% NaCl). Similar, although smaller effects are seen for the alkalis (e.g., $\mathrm{Rb}$ and $\mathrm{Cs}$ ) and the alkaline earths (Sr). Pb, $T h$, and $U$ also show striking increases with salinity. On the other hand, both the typical high field strength elements, such as $\mathrm{Nb}$ and $\mathrm{Ta}$ as well as the heavy rare earth (e.g., Lu) appear to be unaffected by chloride.

Our data for $\mathrm{Cl}$-free aqueous fluids are generally consistent with those from a previous study (Kessel et al., 2005), as shown in Figure 3. For saline fluids, there are no published data 


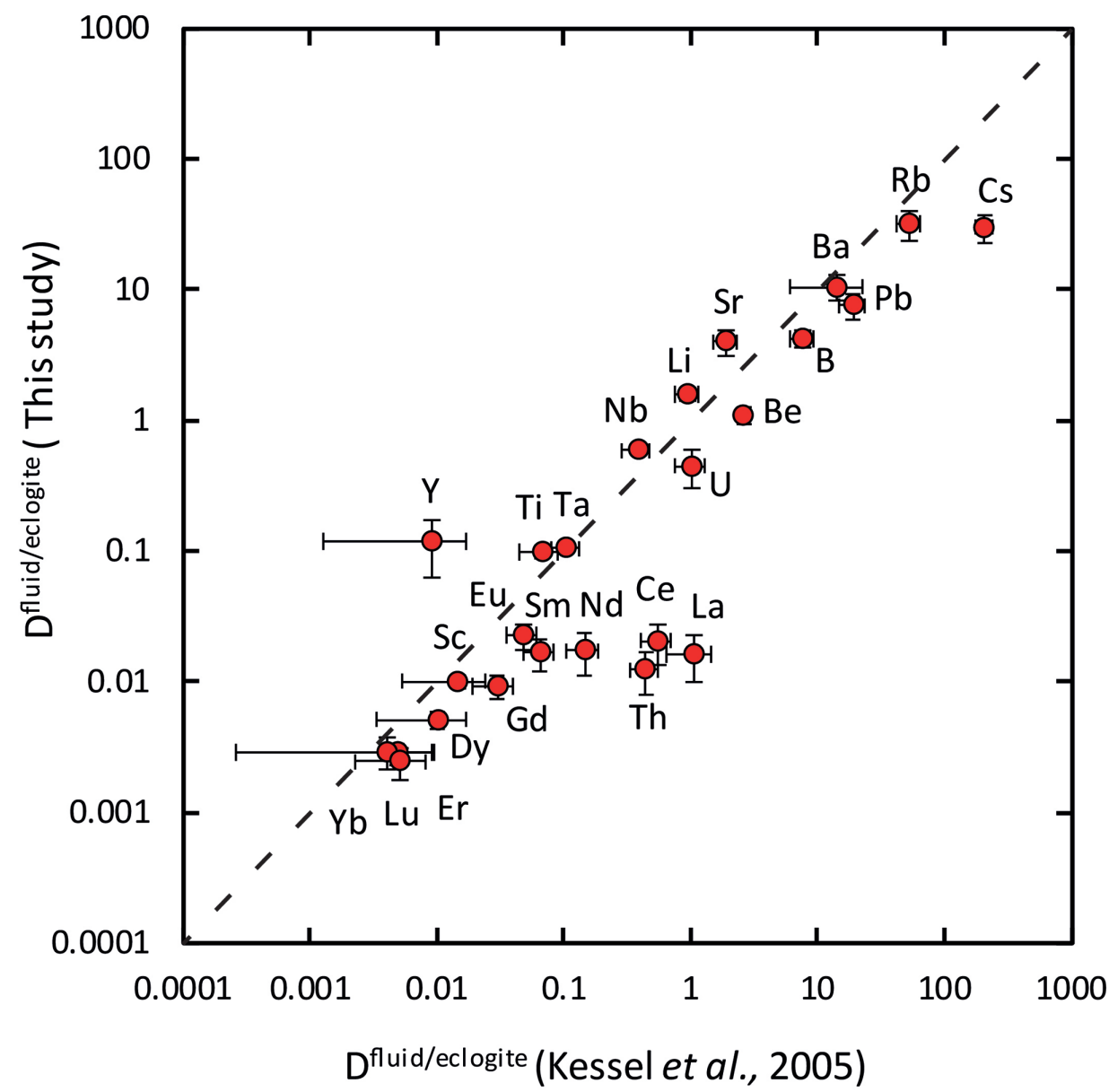

Figure 3 Comparison of the fluid/eclogite partition coefficients for $\mathrm{Cl}$-free fluids measured in this study with those reported by Kessel et al. (2005). Both sets of experiments were carried out at $4 \mathrm{GPa}$ and $800{ }^{\circ} \mathrm{C}$, with a bulk composition resembling MORB.

that could be directly compared with our results. However, both studies on mineral solubilities (Bali et al., 2011; Tropper et al., 2011; Tsay et al., 2014) and fluid/melt partitioning (Keppler, 1996; Kawamoto et al., 2014) at lower pressures suggest that those elements that are affected by fluid salinity indeed form stable chloride complexes in aqueous fluids. In particular, Tsay et al. (2014) noted an increase of the solubility of $\mathrm{La}_{2} \mathrm{Si}_{2} \mathrm{O}_{7}$ and $\mathrm{Nd}_{2} \mathrm{Si}_{2} \mathrm{O}_{7}$ in aqueous fluid by one order of magnitude upon addition of $1.5 \mathrm{M} \mathrm{NaCl}$ at $800{ }^{\circ} \mathrm{C}$ and $2.6 \mathrm{GPa}$. The formation of chloride complexes will tend to stabilise the trace element in the fluid and therefore increase the fluid/eclogite partition coefficient. Only the sensitivity of Th to chloride is unexpected, as it behaves differently from other HFSE trace elements, such as $\mathrm{Nb}$ and $\mathrm{Ta}$. However, the ionic radius of $\mathrm{Th}^{4+}$ is significantly larger than that of $\mathrm{Nb}^{5+}, \mathrm{Ta}^{5+}$, or $\mathrm{Ti}^{4+}$, such that its geochemical behaviour may be transitional between a typical high field strength and a large ion lithophile element. We also tried to measure the fluid/eclogite partitioning of $\mathrm{Zr}$ and $\mathrm{Hf}$, two important HFSE trace elements, but here we encountered experimental problems. The distribution of these elements in the quenched fluid inside the diamond trap was always highly inhomogeneous, which precluded the reliable determination of fluid concentrations and partition coefficients. A possible reason could be the very low solubility (Bernini et al., 2013) of zircon $\mathrm{ZrSiO}_{4}$ and hafnon $\mathrm{HfSiO}_{4}$, which may have precipitated early during the experiment inside the diamond trap and may have failed to reach equilibrium.

Figure 4 shows the trace element enrichment pattern in the fluid phase from the fluid/eclogite partitioning experiments as a function of salinity. An important observation here is that a pure aqueous fluid would not be able to produce all of the trace element enrichment features observed in arc magmas. While such fluids may effectively transport some large ion lithophile elements, like $\mathrm{Rb}, \mathrm{Cs}, \mathrm{Sr}$, and Ba (with fluid/ eclogite partition coefficients $>1$ ), the light rare earths as well as uranium would be retained in the eclogite. This used to be one of the main arguments why aqueous fluids were considered to be "too dilute" to produce the trace element enrichment observed in arc magmas and why alternative mechanisms, such as metasomatism by sediment melt were proposed. However, for elevated salinities the enrichment pattern in aqueous fluid has a striking similarity to that observed in arc magmas, with the light rare earths and $U$ becoming mobile in the fluid together with the large ion lithophile elements, while at the same time, high field strength elements, such as $\mathrm{Nb}, \mathrm{Ta}$, and Ti are nearly completely retained in the eclogite. The high $\mathrm{Ba} / \mathrm{La}, \mathrm{Ba} / \mathrm{Nb}$, and $\mathrm{U} / \mathrm{Th}$ ratios match well with those inferred from primitive arc basalts (see Supplementary Information for further discussion). In particular, the "negative $\mathrm{Nb}-\mathrm{Ta}$ anomaly" i.e. the strong depletion of $\mathrm{Nb}$ and Ta relative to both light rare earths and large ion lithophile elements is a hallmark of subduction zone magmas. Saline fluids can fractionate these elements by three orders of magnitude, mainly through the effect of $\mathrm{Cl}$ on rare earth partitioning. In a chloride-free system, the fluid/eclogite partition coefficient of La and Ce could be increased to a similar value by a temperature increase of several $100{ }^{\circ} \mathrm{C}$, ultimately leading to melting (Kessel et al., 2005). However, in silicate melts, $\mathrm{Nb}$ and $\mathrm{Ta}$ would also become mobile and therefore, this effect cannot produce the negative $\mathrm{Nb}$ Ta anomaly observed in subduction zone magmas. 


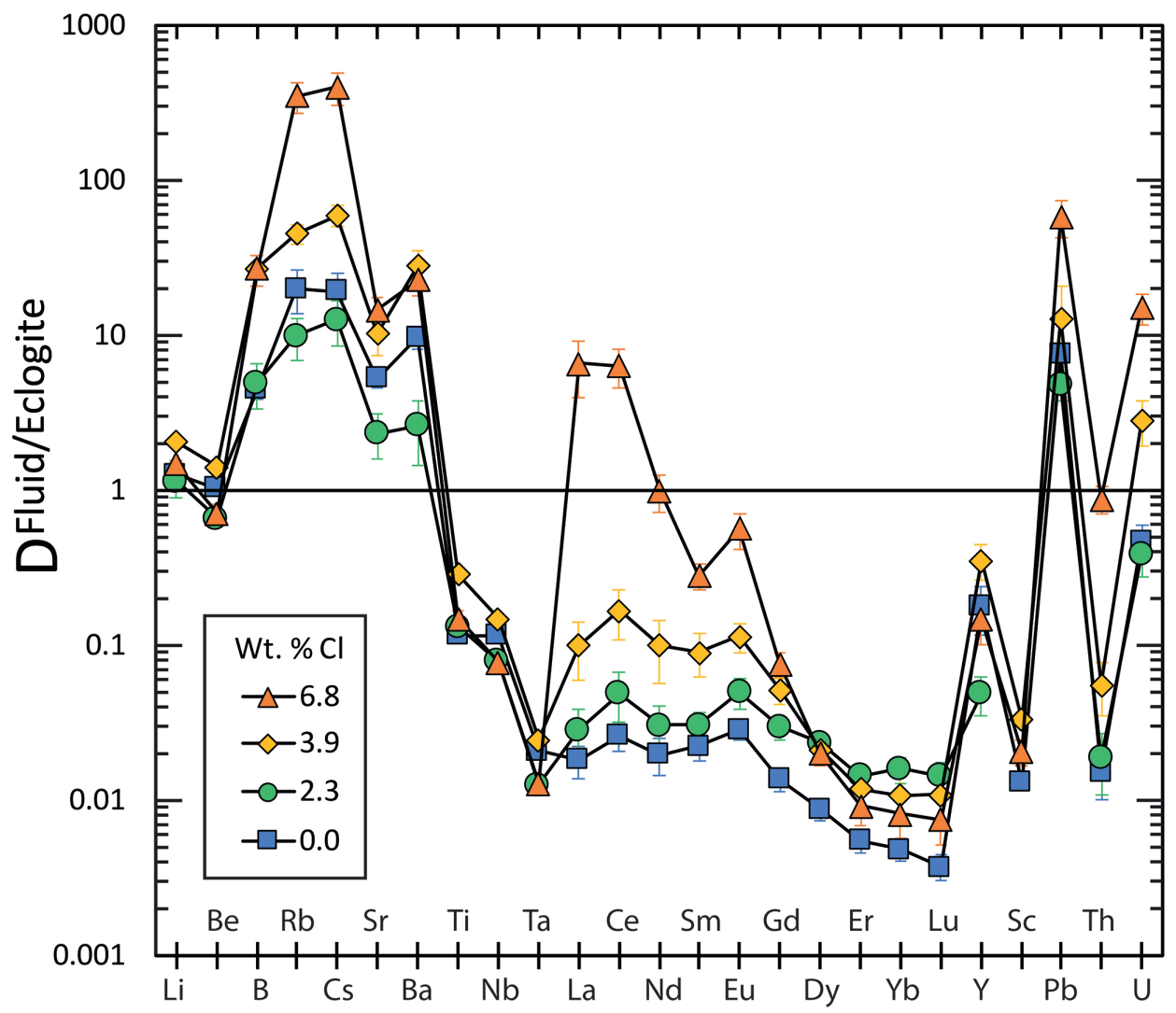

Figure 4 Trace element enrichment patterns in fluids from fluid/eclogite partitioning experiments at $4 \mathrm{GPa}$ and $800{ }^{\circ} \mathrm{C}$. Error bars are one standard deviation. Data for these and additional elements are given in Tables S-1 to S-8.

\section{Conclusions}

Our experimental data show that saline fluids released from the basaltic layer of the subducted slab can account for most features in the trace element enrichment pattern observed in subduction zone magmas. In the light of these experiments, the relative importance of aqueous fluids and sediment melts in the formation of arc magmas needs to be reconsidered. Strong evidence for the involvement of sedimentary material comes from isotopic data; already Armstrong (1971) noted a close correlation between the ${ }^{206} \mathrm{~Pb} /{ }^{204} \mathrm{~Pb}$ ratio of arc magmas and the sediments in front of some arcs and similar evidence has been presented for different isotope systems. However, these observations do not necessarily require the involvement of sediment melts. The isotopic signal observed may also have been transported by aqueous fluids; our data suggest that both $\mathrm{Pb}$ and $\mathrm{Sr}$ may be efficiently transported by saline fluids (Fig. 4) and even Be and $\mathrm{Nd}$ may be significantly mobile under some conditions. High Th/La ratios in arc magmas may be inherited from sediments (Plank, 2005); however, it remains uncertain whether sediment melts could effectively transport these elements, as they are strongly retained in residual monazite and other phases and the fractionation of Th and La between melt and monazite may not always operate in the right direction (Skora and Blundy, 2010). On the other hand, experimental data suggest that mantle metasomatism by sediment melts produces distinctly potassic melts (Mallik et al., 2015) different from average subduction zone magmas. Thermal models of subduction zones (Syracuse et al., 2010) suggest temperatures below the arc that are lower than those required for dehydration melting (e.g., Mann and Schmidt, 2015). Higher temperatures have been inferred from $\mathrm{Ce} / \mathrm{H}_{2} \mathrm{O}$ ratios. However, the $\mathrm{Ce} / \mathrm{H}_{2} \mathrm{O}$ geothermometer (Plank et al., 2009) is based on the assumption that the $\mathrm{Ce} / \mathrm{H}_{2} \mathrm{O}$ ratio in fluids and melts is a function of temperature only. Our data (Fig. 2) show that at the same temperature, this ratio may vary by three orders of magnitude as a function of salinity.

\section{Acknowledgements}

We thank Patrick O’Brien for discussing some aspects of eclogite mineralogy with us. Reviews by Matthieu Galvez and by an anonymous referee helped to improve the manuscript. This work was supported by the DFG International Research Training Group “Deep Earth Volatile Cycles” (GRK 2156/1).

Editor: Cin-Ty Lee

\section{Additional Information}

Supplementary Information accompanies this letter at http:// www.geochemicalperspectivesletters.org/article1925.

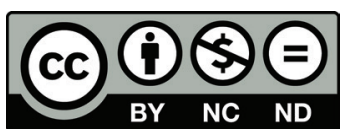

This work is distributed under the Creative Commons Attribution Non-Commercial No-Derivatives 4.0 License, which permits unrestricted distribution provided the original author and source are credited. The material may not be adapted (remixed, transformed or built upon) or used for commercial purposes without written permission from the author. Additional information is available at http://www.geochemicalperspectivesletters.org/ copyright-and-permissions.

Cite this letter as: Rustioni, G., Audétat, A., Keppler, H. (2019) Experimental evidence for fluid-induced melting in subduction zones. Geochem. Persp. Let. 11, 49-54. 


\section{References}

ARCUlus, R.J., POWELL, R. (1986) Source component mixing in the regions of arc magma generation. Journal of Geophysical Research 91, 5913-5926.

ARMSTRONG, R.L. (1971) Isotopic and chemical constraints on models of magma genesis in volcanic arcs. Earth and Planetary Science Letters 12 37-142

Bali, E., Audetat, A., Keppler, H. (2011) The mobility of U and Th in subduction zone fluids: an indicator of oxygen fugacity and fluid salinity. Contributions to Mineralogy and Petrology 161, 597-613.

Behn, M.D., Kelemen, P.B., Hirth, G., Hacker, B.R., Massonne, H.J. (2011) Diapirs as the source of the sediment signature in arc lavas. Nature Geoscience 4, 641-646.

Bernini, D., Audetat, A., Dolejs, D., Keppler, H. (2013) Zircon solubility in aqueous fluids at high temperatures and pressures. Geochimica et Cosmochimica Acta 119, 178-187.

BOYD, F.R., ENGLAND, J.L. (1960) Apparatus for phase-equilibrium measurements at pressures up to 50 kilobars and temperatures up to $1750^{\circ} \mathrm{C}$ Journal of Geophysical Research 65, 741-748.

Carter, L.B., Skora, S., Blundy, J.D., De Hoog, J.C.M., Elliott, T. (2015) An experimental study of trace element fluxes from subducted oceanic crust. Journal of Petrology 56, 1585-1606.

Gaetani, G.A., GROVE, T.L. (1998) The influence of water on melting of mantle peridotite. Contributions to Mineralogy and Petrology 131, 323-346.

Hermann, J., Spandler, C., Hack, A., Korsakov, A.V. (2006) Aqueous fluids and hydrous melts in high-pressure and ultra-high pressure rocks: Implications for element transfer in subduction zones. Lithos 92, 399-417.

KaWAmoto, T., Holloway, P.R. (1997) Melting temperature and partia melt chemistry of $\mathrm{H}_{2} \mathrm{O}$-saturated mantle peridotite to 11 gigapascals. Science 276, 240-243.

Kawamoto, T., Yoshikawa, M., Kumagai, Y., Mirabueno, M.H.T OKunO, M., Kobayashi, T. (2013) Mantle wedge infiltrated with saline fluids from dehydration and decarbonation of subducting slab. Proceedings of the National Academy of Sciences of the USA 110, 9663-9668.

Kawamoto, T., Mibe, K., Bureau, H., Reguer, S., Mocuta, C., Kubsky, S., Thiaudiere, D., OnO, S., Kogiso, T. (2014) Large-ion lithophile elements delivered by saline fluids to the sub-arc mantle. Earth, Planets and Space 66, doi:10.1186/1880-5981-66-61.

Kelemen, P.B., HanghøJ, K., Greene, A.R. (2005) One view of the geochemistry of subduction-related magmatic arcs, with an emphasis on primitive andesite and lower crust. In: Rudnick, R.L. (Ed.) Treatise of Geochemistry, Volume 3, The Crust. Elsevier, Amsterdam, 593-659.

KePpler, H. (1996) Constraints from partitioning experiments on the composition of subduction-zone fluids. Nature 380, 237-240.

Kessel, R., Schmidt, M.W., Ulmer, P., Pettke, T. (2005) Trace element signature of subduction-zone fluids, melts and supercritical liquids at 120-180 km depth. Nature 437, 724-727.

KonZETT, J., Frost, D.J. (2009) The high P-T stability of hydroxyl-apatite in natural and simplified MORB - an experimental study to $15 \mathrm{GPa}$ with implications for transport and storage of phosphorus and halogens in subduction zones. Journal of Petrology 50, 2043-2062

Mallik, A., Nelson, J., Dasgupta, R. (2015) Partial melting of fertile peridotite fluxed by hydrous rhyolitic melt at 2-3 GPa: implication for mantle wedge hybridization by sediment melt and generation of ultrapotassic magmas in convergent margins. Contributions to Mineralogy and Petrology 169, Article Number 48.

MANN, U., SchMidT, M.W. (2015) Melting of pelitic sediments at subarc depths: 1 . Flux vs. fluid-absent melting and a parameterization of mel productivity. Chemical Geology 404, 150-167.

MANNING, C.E. (2004) The chemistry of subduction zone fluids. Earth and Planetary Science Letters 223, 1-16.

MÉTrich, N., Wallace, P.J. (2008) Volatile abundances in basaltic magmas and their degassing paths tracked by melt inclusions. Reviews in Mineralogy and Geochemistry 69, 363-402.

Okrusch, M., Matthes, S., Klemd, R., O’Brien P.J., Schmidt, K. (1991) Eclogites at the north-western margin of the Bohemian Massif: A review. European Journal of Mineralogy 3, 707-730.

Perfit, M.R., Gust, D.A., Bence, A.E., Arculus, R.J., Taylor, S.R. (1980) Chemical characteristics of island-arc basalts - implications fo mantle sources. Chemical Geology 30, 227-256.

PLANK, T. (2005) Constraints from thorium/lanthanum on sediment recycling at subduction zones and the evolution of the continents. Journal of Petrology 46, 921-944.
Plank, T., Cooper, L.B., Manning, C.E. (2009) Emerging geothermometers for estimating slab surface temperatures. Nature Geoscience, 2, 611-615.

Ryabchikov, I.D., Orlova, G.P., Kalenchuk, G.Y., GaneyeV, I.I., Udovkina, N.G., NosIK, L.P. (1989) Reactions of spinel lherzolite with $\mathrm{H}_{2} \mathrm{O}-\mathrm{CO}_{2}$ fluids at $20 \mathrm{kbar}$ and $900{ }^{\circ} \mathrm{C}$. Geochemistry International $26,56-62$.

SKORA, S., BLUNDY, J. (2010) High-pressure hydrous phase relations of radiolarian clay and implications for the involvement of subducted sediment in arc magmatism. Journal of Petrology 51, 2211-2243.

SPANDlER, C., PIRARD, C. (2013) Element recycling from subducting slabs to arc crust: A review. Lithos 170-171, 208-223.

Syracuse, E.M., Van Keken, P.E., Abers, G.A. (2010) The global range of subduction zone thermal models. Physics of the Earth and Planetary Interiors 183, 73-90.

Tropper, P., Manning, C.E., Harlov, D.E. (2011) Solubility of $\mathrm{CePO}_{4}$ monazite and $\mathrm{YPO}_{4}$ xenotime in $\mathrm{H}_{2} \mathrm{O}$ and $\mathrm{H}_{2} \mathrm{O}-\mathrm{NaCl}$ at $800{ }^{\circ} \mathrm{C}$ and $1 \mathrm{GPa}$ : Implications for REE and $\mathrm{Y}$ transport during high-grade metamorphism. Chemical Geology 282, 58-66.

TSAY, A., ZAJACZ, Z., SANCHEZ-VALLE, C. (2014) Efficient mobilization and fractionation of rare-earth elements by aqueous fluids upon slab dehydration. Earth and Planetary Science Letters 398, 101-112. 